\title{
Mycorrhiza-Induced Changes in Disease Severity and PR Protein Expression in Tobacco Leaves
}

\author{
Orna Shaul, ${ }^{1}$ Shmuel Galili, ${ }^{1}$ Hanne Volpin, ${ }^{1}$ Idit Ginzberg, ${ }^{1}$ Yigal Elad, ${ }^{1}$ Ilan Chet, ${ }^{2}$ and \\ Yoram Kapulnik ${ }^{1}$ \\ ${ }^{1}$ Agricultural Research Organization, The Volcani Center, Bet Dagan 50250, Israel; ${ }^{2}$ The Department of \\ Plant Pathology and Microbiology, Faculty of Agriculture, The Hebrew University of Jerusalem, Rehovot \\ 76100 , Israel \\ Accepted 12 July 1999.
}

The development of leaf disease symptoms and the accumulation of pathogenesis-related (PR) proteins were monitored in leaves of tobacco (Nicotiana tabacum cv. Xanthinc) plants colonized by the arbuscular mycorrhizal fungus Glomus intraradices. Leaves of mycorrhizal plants infected with the leaf pathogens Botrytis cinerea or tobacco mosaic virus showed a higher incidence and severity of necrotic lesions than those of nonmycorrhizal controls. Similar plant responses were obtained at both low $(0.1 \mathrm{mM})$ and high (1.0 mM) nutritional $P$ levels and with mutant plants (NahG) that are unable to accumulate salicylic acid. Application of PR-protein activators induced PR-1 and PR-3 expression in leaves of both nonmycorrhizal and mycorrhizal plants; however, accumulation and mRNA steady-state levels of these proteins were lower, and their appearance delayed, in leaves of the mycorrhizal plants. Application of $0.3 \mathrm{mM}$ phosphate to the plants did not mimic the delay in PR expression observed in the mycorrhizal tobacco. Together, these data strongly support the existence of regulatory processes, initiated in the roots of mycorrhizal plants, that modify disease-symptom development and gene expression in their leaves.

Additional keywords: chitinase, 2,6-dichloroisonicotinic acid (INA), symbiosis, (1,2,3)-thiadiazole-7-carbothioic acid Smethyl ester (BTH), thiamine, UV.

Arbuscular mycorrhiza (AM) fungi are obligate symbiotic microorganisms that form associations with plant roots in a host-nonspecific manner. About $80 \%$ of land plant species form mycorrhizae (Bonfante-Fasolo 1987) and their occurrence has been reported in many ecosystems. The fungi have been shown to promote plant growth, mainly by enhancing nutrient acquisition (Harley and Smith 1983), producing plant growth hormones, improving rhizospheric and soil conditions

Corresponding author: Y. Kapulnik; Agronomy and Natural Resources, ARO, The Volcani Center, Bet Dagan 50250, Israel; Fax: 972-39669642; E-mail: Kapulnik@ Agri.Huji.ac.IL

Contribution from the Agricultural Research Organization, The Volcani Center, Bet Dagan 50250, Israel, No. 167/98 series.

This paper is dedicated to the memory of Orna Shaul, who unexpectedly passed away during the preparation of the manuscript for publication. This work was part of her Ph.D. studies.
(Linderman 1994), altering host physiological and biochemical properties (Smith and Read 1995), and defending roots against soilborne diseases (Dehne 1982; Schönbeck and Dehne 1979).

Whereas soilborne diseases are most often reduced in mycorrhizal plants, those caused by foliar pathogens generally increase (Schönbeck and Dehne 1979; Dehne 1982). Based on the development of leaf symptoms, Dehne (1982) pointed out that the aerial parts of AM plants become more susceptible to both obligate and nonobligate leaf pathogens. Retardation of senescence was regarded as a potential reason for this phenomenon, particularly the increased susceptibility to biotrophic leaf pathogens, as they are highly dependent on the supply of assimilates in the host leaves (Meyer and Dehne 1986). Nevertheless, no biochemical evidence of this mechanism has been presented to date. Infection of plant leaves with certain pathogens usually leads to the appearance of soluble pathogenesis-related (PR) proteins in the infected tissue (van Loon 1985). At least five gene families (PR-1 to PR-5) coding for PR proteins have been described, including both their basic and acidic subfamilies (Bol et al. 1990). The involvement of PR proteins in enhancing plant resistance to pathogens has been suggested (Métraux and Boller 1986; Wyatt et al. 1991; Young and Hwang 1994), and overexpression of a variety of PR genes in transgenic plants enhances their resistance to various fungal pathogens (Broglie et al. 1991; Alexander et al. 1993; Liu et al. 1994; Yoshikawa et al. 1994; Zhu et al. 1994). These findings and the finding that, in inoculated resistant and susceptible plants, PR proteins are induced systemically in noninfected tissue, may indicate a role for PR proteins in systemic acquired resistance (SAR) (Ross 1961; Kúc 1982), and may also indicate that endogenous signals are involved in the induction of several plant defense responses (Conrath et al. 1997).

In AM fungally infected tissue, only weak and transient PR gene expression has been observed (Lambais and Mehdy 1994). Furthermore, overexpression of PR genes in transgenic tobacco plants did not reduce the infection or colonization of roots by the AM fungus Glomus mosseae (Vierheilig et al. 1995). In fact, suppression of PR-1 and PR-3 gene expression in mycorrhizal tobacco roots has been demonstrated (David et al. 1998; Ginzberg et al. 1998). So far, it is not known whether this suppression is systemic or restricted to the infected zone, e.g., whether AM inoculation in the roots also affects leaf re- 
sponse to foliar pathogens. Although the molecular and biochemical mechanisms that mediate transduction from root to shoot are not yet clear, synthesis of the PR proteins could serve as a convenient molecular marker for plant disease resistance and for the induction or suppression of mechanisms associated with plant resistance.

In the present study, we focused on the development of disease symptoms in leaves of mycorrhizal plants, following inoculation with the fungal pathogen Botrytis cinerea or tobacco mosaic virus (TMV). In addition, the expression rates of PR-1 and PR-3 were determined following the application of PR inducers.

\section{RESULTS}

\section{Plant growth and disease development.}

To study changes in the development of foliar disease symptoms during AM symbiosis, tobacco plants were grown in the absence $(-\mathrm{AM})$ or presence $(+\mathrm{AM})$ of the mycorrhizal fungus $G$. intraradices. Six weeks after planting, mycorrhizal plants showed $75 \%$ root infection with no significant differences between their growth rate and that of the nonmycorrhizal plants, expressed as biomass accumulation (50 \pm 3 and 45 $\pm 5 \mathrm{~g}$ of dry weight per plant for noninoculated and inoculated plants, respectively).

The influence of AM symbiosis on the development of disease symptoms induced by the foliar pathogens $B$. cinerea or TMV was tested on the first fully expanded leaf of 6-week-old plants. Disease severity induced by $B$. cinerea (estimated as lesion development following application of eight droplets on one leaf) or by TMV (estimated as the total lesion area in the infected region) was significantly higher on leaves of mycorrhizal plants than on those of the nonmycorrhizal controls (Fig. 1). The lesions induced by $B$. cinerea continued to increase in size with time and appeared as restricted necrotic areas within the area of the fungal inoculation droplets. TMV-

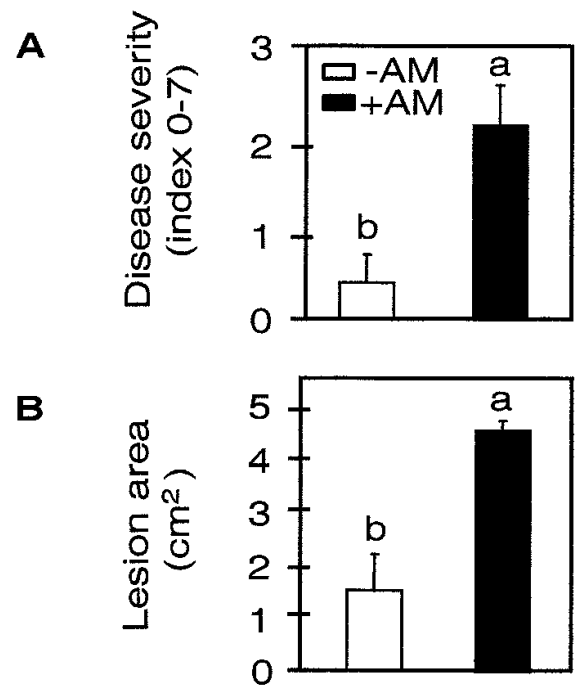

Fig. 1. Necrotic lesion development on leaves of mycorrhizal (ם) and nonmycorrhizal ( $\square$ ) plants, following inoculation with (A) Botrytis cinerea or (B) tobacco mosaic virus: disease severity and lesion area were determined, respectively. Disease severity was evaluated on a 0-7 scale in which $0=$ healthy and $7=$ lesions that developed as far as $4 \mathrm{~mm}$ out of the inoculation drop. induced lesions, on the other hand, were surrounded by a brown ring of cells 4 days after inoculation. Further experiments were performed with $B$. cinerea as the fungal foliar pathogen.

The effect of leaf position on lesion development following B. cinerea inoculation was examined $48 \mathrm{~h}$ after inoculation of 6-week-old tobacco plants. Older leaves, of both mycorrhizal and nonmycorrhizal plants, exhibited higher disease severity than younger ones (Fig. 2). A comparison of disease severity between individual leaves of mycorrhizal plants and their corresponding leaves from nonmycorrhizal controls indicated that the first to fifth leaves from the top show greater disease severity in mycorrhizal plants than in nonmycorrhizal plants (Fig. 2). The rate of disease severity attained by different leaves of mycorrhizal plants was significantly higher $(P=$ 0.0474 , as analyzed by $t$ test comparing the two regression lines, shown in Figure 2) than that attained by leaves of nonmycorrhizal plants. Thus, AM symbiosis enhances disease symptom development on plant leaves, with the highest level of enhancement observed on the youngest leaves.

Time-course experiments were carried out to establish the potential relationships between (i) the P level (normally enhanced in the plant throughout the mycorrhizal symbiosis), (ii) the rate of symptom development, and (iii) the lesion size developed on tobacco leaves. To enable the initiation of mycorrhizal infection, all treatments received $0.1 \mathrm{mM}$ phosphate for 14 days. Plants treated with the high $\mathrm{P}$ level received 1.0 $\mathrm{mM}$ phosphate in the nutrient solution, starting on day 14 . When the plants were sampled at 5 weeks, the mycorrhizal colonization rate of those treated with the high $\mathrm{P}$ level (1.0 $\mathrm{mM})$ was $27 \%$ and that of those receiving the low P level $(0.1$ $\mathrm{mM}$ ) was $78 \%$. Phosphorous content in leaves of plants grown under low and high P nutrition levels was $2.16 \pm 0.17$ and 4.05 $\pm 0.14 \mathrm{mg}$ per $\mathrm{kg}$ of dry weight, respectively. Phosphorous content in leaves of mycorrhizal plants grown under low $\mathrm{P}$ level was $2.10 \pm 0.15 \mathrm{mg}$ per $\mathrm{kg}$ of dry weight. At both phosphorous nutritional levels leaves of mycorrhizal plants showed an accelerated rate of development of lesions, compared with those developed on nonmycorrhizal plants (Fig. 3A and B). At low $\mathrm{P}$ nutrition, rates of symptom development (analyzed

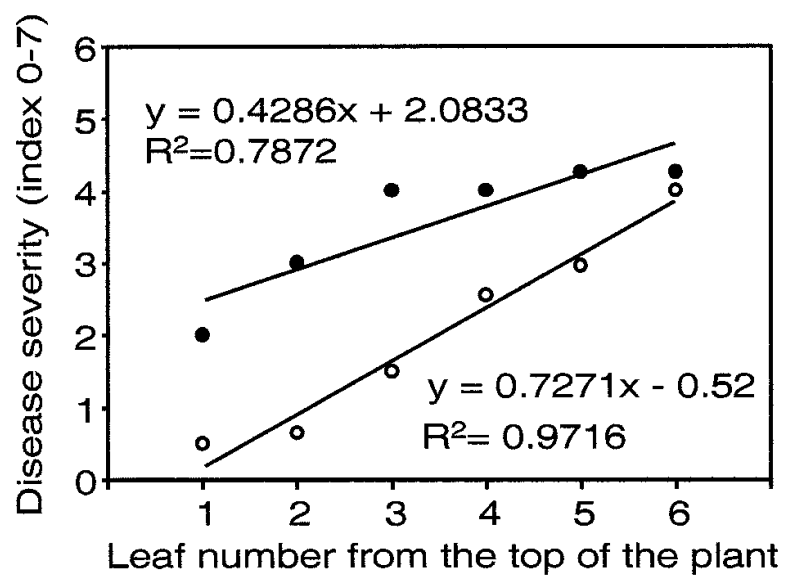

Fig. 2. Severity of necrotic lesions caused by Botrytis cinerea on leaves of various ages $(1=$ top $=$ young, $6=$ bottom $=$ old $)$ of mycorrhizal $(\bullet)$ and nonmycorrhizal $(\mathrm{O})$ tobacco plants. Disease was evaluated $48 \mathrm{~h}$ after Botrytis cinerea inoculation. Formulae describe the relationship between disease severity and leaf position. 
from regression lines) in leaves of mycorrhizal plants were found to be significantly different $(P=0.015)$ from rates observed in nonmycorrhizal plants. Similarly, at high P nutrition, rates of symptom development on mycorrhizal plant leaves were significantly higher $(P<0.001)$ than rates obtained with nonmycorrhizal plants. These results suggested that the increase in disease severity of mycorrhizal tobacco plants is not linked to the elevated $\mathrm{P}$ nutrition but to another mycorrhizaassociated factor(s). Moreover, leaves of mycorrhizal plants responded similarly when detached from the plant prior to inoculation with $B$. cinerea (Fig. 3C). Leaf disease severity of mycorrhizal and nonmycorrhizal plants was different $(P \leq$ $0.05)$ at 48 and $72 \mathrm{~h}$ after $B$. cinerea application. However, the rates of symptom development during the entire incubation time were not different $(P=0.227)$. Nevertheless, it is possible that susceptibility to $B$. cinerea infection was predetermined in the leaves prior to sampling.

To assess the involvement of the salicylic acid (SA) signal in transmitting the "mycorrhizal-induced symptom-development effect" to the leaves, a tobacco mutant (NahG) that is not able to accumulate SA (Gaffney et al. 1993) was used in leafinfection studies with TMV. The number and size of developing symptoms were monitored in the leaves of mycorrhizal

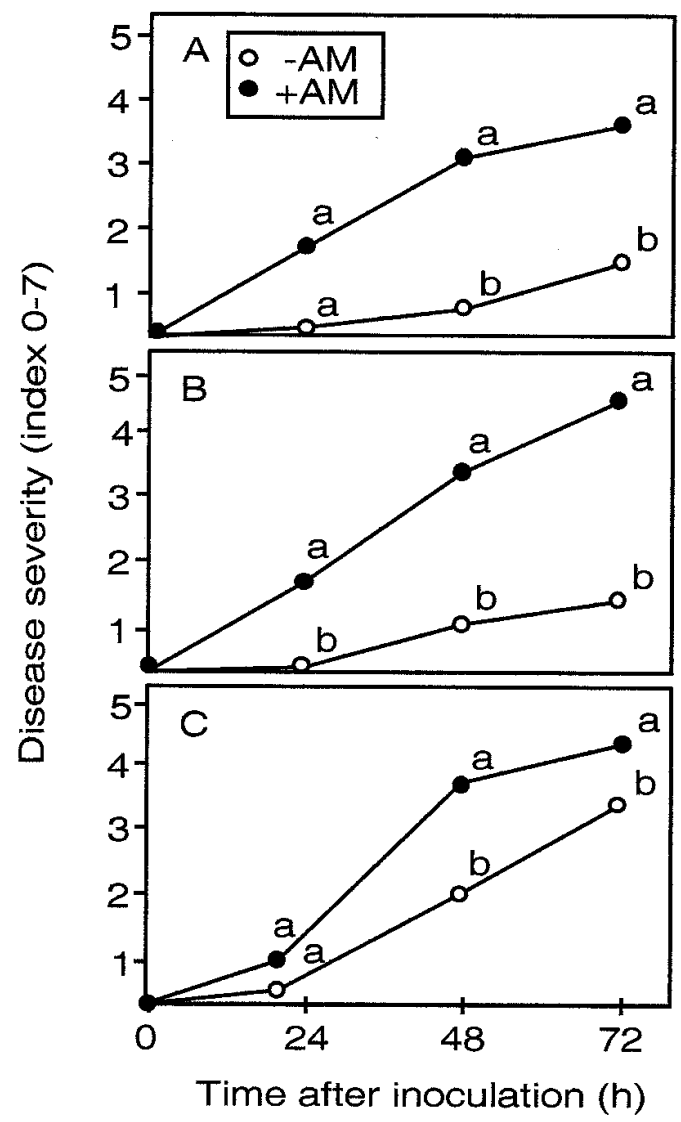

Fig. 3. Development of necrotic lesions induced by Botrytis cinerea on leaves of mycorrhizal (•) and nonmycorrhizal (O) tobacco plants, watered with (A) 0.1 or (B) $1.0 \mathrm{mM}$ phosphate, or (C) on detached leaves taken from plants that had received $0.3 \mathrm{mM}$ phosphate. Disease severity was evaluated on a 0-7 scale (see Figure 1 caption). Values followed by the same letter ( $\mathrm{a}$ or $\mathrm{b}$ ) do not differ significantly $(P \leq 0.05)$ for the same sampling time. and nonmycorrhizal plants and the lesion area in the infected leaves was calculated. Lesions were significantly larger in the mycorrhizal plants of both Xanthi-nc and the mutant (Table 1), indicating that SA accumulation is not a prerequisite for induced symptom development following AM establishment.

\section{PR protein accumulation.}

To monitor modifications in the defense response of mycorrhizal plants, several Western blot (immunoblot) tests were used to analyze the accumulation of PR-1 and PR-3 proteins in leaves of mycorrhizal and nonmycorrhizal tobacco plants. Rather than pathogens, UV irradiation and chemical activators of PR proteins were used to induce the plant defense response. After exposure of leaves to UV light for 1,5 , or $10 \mathrm{~min}$, plants were incubated for $48 \mathrm{~h}$ under controlled conditions and total proteins were extracted from the treated leaves. Immunodetection of the PR-1 protein revealed that, after $1 \mathrm{~min}$ of UV exposure, this protein had accumulated in the leaves of the nonmycorrhizal plants; in contrast, it could only be detected in mycorrhizal leaves after $5 \mathrm{~min}$ of exposure (Fig. 4). These data indicate that AM colonization in the roots induces an active mechanism that causes delayed accumulation of PR-1 protein in response to a short exposure to UV. Similarly, following application of the chemical inducers thiamine, SA, and 2,6-dichloroisonicotinic acid (INA), the accumulation of PR-1 and PR-3 proteins in leaves of mycorrhizal plants could only be detected at later sampling times, relative to nonmycorrhizal controls (Fig. 5).

To verify whether the delayed accumulation of PR-1 protein in leaves of mycorrhizal plants resulted from the biotic supply of $\mathrm{P}$ via the mycorrhizal fungus, plants were treated with an alternative PR inducer, (1,2,3)-thiadiazole-7-carbothioic acid $\mathrm{S}$-methyl ester (BTH), and were watered with either 0.1 or 0.3 $\mathrm{mM}$ phosphate, resulting in comparable growth rates and $\mathrm{P}$ contents in the plants. At harvest, $\mathrm{P}$ contents in the first fully expanded leaves were $1.5 \pm 0.1$ and $2.2 \pm 0.2 \mathrm{mg}$ per $\mathrm{kg}$ of dry weight for nonmycorrhizal and phosphate-treated plants, respectively, and $1.8 \pm 0.1 \mathrm{mg}$ per $\mathrm{kg}$ of dry weight for my-

Table 1. Severity of tobacco mosaic virus (TMV) symptoms of tobacco Xanthi-nc (wild type) or mutant (NahG) leaves in mycorrhizal (+AM) and nonmycorrhizal (-AM) plants

\begin{tabular}{lcc}
\hline Plant genotype & Mycorrhizal inoculation & Lesion area $\left(\mathbf{m m}^{\mathbf{2}} \pm \mathbf{S E}\right)$ \\
\hline Wild type & $-\mathrm{AM}$ & $12.3 \pm 5.1$ \\
& $+\mathrm{AM}$ & $46.5 \pm 5.7$ \\
NahG & -AM & $54.9 \pm 19.5$ \\
& $+\mathrm{AM}$ & $107.4 \pm 17.3$ \\
\hline
\end{tabular}

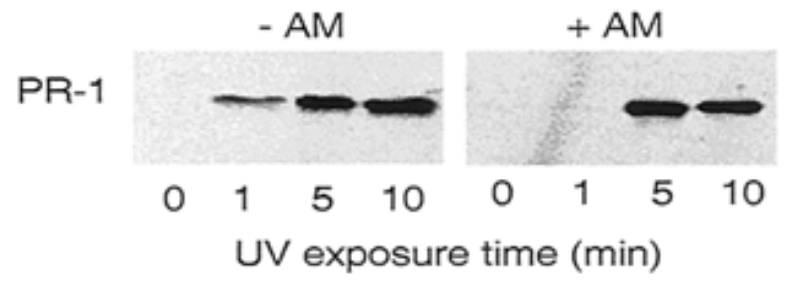

Fig. 4. Effect of UV exposure time of mycorrhizal (+AM) and nonmycorrhizal (-AM) plant leaves on accumulation of tobacco PR-1 protein. Plants were exposed to one UV irradiation pulse and incubated for $48 \mathrm{~h}$ before sampling. Proteins were extracted at different time points, as indicated and analyzed by Western blot (immunoblot), probed with antibodies directed against PR-1. 
corrhizal plants grown at low P. PR-1 protein was detected 24 $\mathrm{h}$ post BTH application in leaves of nonmycorrhizal plants treated with either low $(0.1 \mathrm{mM})$ or high $(0.3 \mathrm{mM}) \mathrm{P}$, but its accumulation in mycorrhizal plants could not be detected until $96 \mathrm{~h}$ post BTH application (Fig. 6). These results indicate that mineral $\mathrm{P}$ cannot mimic the observed effect of mycorrhizae in delaying the accumulation of PR proteins.

\section{PR transcript accumulation.}

In earlier studies, we demonstrated that mycorrhizal roots exhibit suppressed expression of PR genes, followed by delayed accumulation of the relevant proteins in colonized roots relative to nonmycorrhizal ones (David et al. 1998; Ginzberg et al. 1998). To correlate the delayed accumulation of PR-1 and PR-3 proteins in the leaves with gene expression, the steady-state mRNA levels of these genes were analyzed from the same leaf samples used for the immunoblot assay. Since the delays in protein accumulation caused by the various PR activators were comparable, two representative activators were chosen to be presented here: UV irradiation and the chemical inducer INA. The accumulation of PR-1a and bPR-3 transcripts following a short exposure to UV was delayed in leaves of mycorrhizal plants, compared with nonmycorrhizal controls (Fig. 7). Similarly delayed transcript accumulation in leaves of mycorrhizal plants was observed when plants were treated with INA (Fig. 8). These results indicate that the delayed PR protein accumulation is due to late induction of expression of these genes in the mycorrhizal plant.

\section{DISCUSSION}

The influence exerted by AM fungi on plant disease development was studied in tobacco leaves inoculated with the necrotrophic leaf pathogen $B$. cinerea or with TMV. The AM fungus $G$. intraradices altered the plant's response to these leaf pathogens, resulting in necrotic lesion symptoms that appeared earlier and grew larger than those developed on nonmycorrhizal plants (Figs. 1, 2, 3). Elad (1995) suggested that the earlier appearance of lesions, which grow to a larger size, indicates sensitivity to a given pathogen. Moreover, the occurrence of necrotic lesions that became visible earlier in my- corrhizal versus nonmycorrhizal plants with a high level of $\mathrm{P}$ nutrition (Fig. 3B) reinforces the conclusion that the improved $\mathrm{P}$ uptake associated with mycorrhization (Harley and Smith 1983 ) is not the biochemical factor modifying the plant's response to B. cinerea (Fig. 3A, B). Finally, the fact that the altered response to $B$. cinerea was observed in detached leaves of mycorrhizal plants (Fig. 3C) indicates that the necessary biochemical change was induced before leaf detachment.

The mechanism(s) by which the expression of these events is modulated by the AM symbiosis is not yet understood. Growth characteristics, biomass production, and micronutrition concentrations did not differ significantly between the mycorrhizal plants and the nonmycorrhizal controls (O. Shaul, $\mathrm{S}$. Wininger, and Y. Kapulnik, data not shown), indicating that the observed effects were not caused (directly) by changes in the growth pattern of AM-infected plants; rather, they may have been caused by the occurrence of a more specific regulatory mechanism(s) associated with AM fungal colonization in the roots.

In some plant-pathogen interactions, it is postulated that, during the formation of necrotic lesions, a signal is produced and conveyed/transduced by a signal transduction pathway to initiate a defensive response to pathogen attack (Ryals et al. 1994). This process is tightly correlated with the expression of PR proteins (Ward et al. 1991a, 1991b), and can be localized

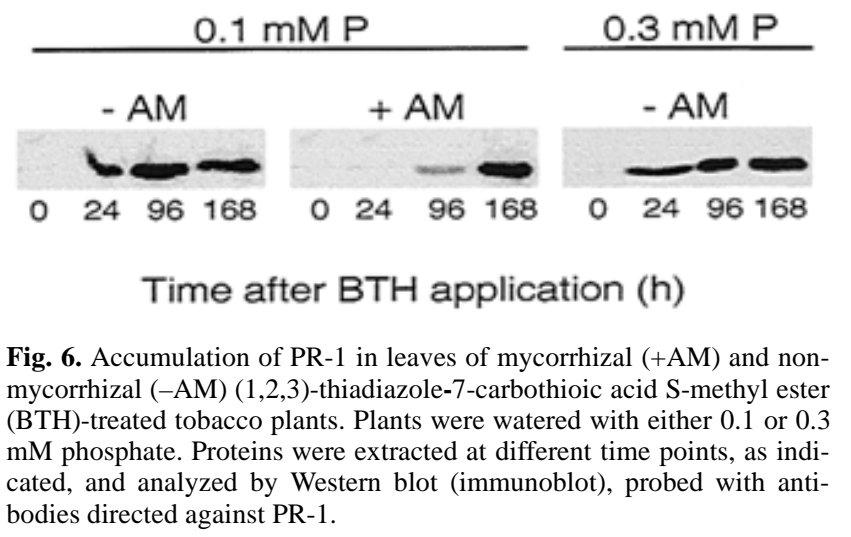

PR-1

PR-3

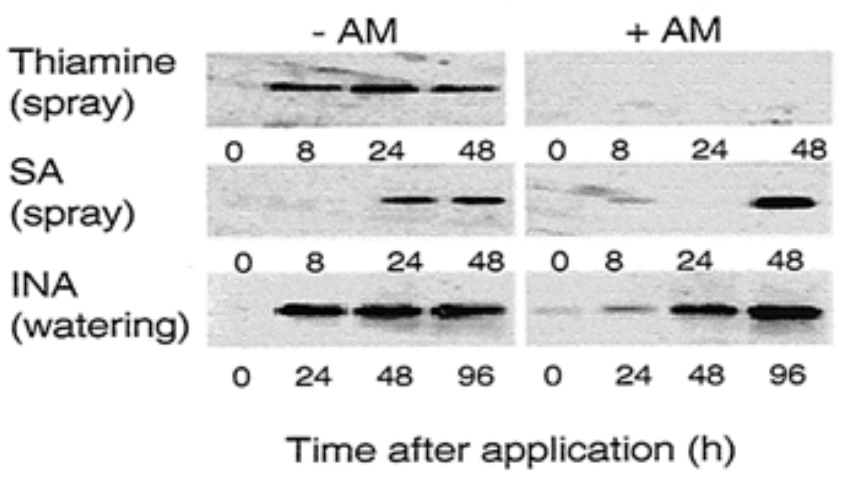

Fig. 5. Accumulation of PR-1 and PR-3 proteins in mycorrhizal (+AM) and nonmycorrhizal (-AM) leaves of chemically induced plants. Thiamine and salicylic acid (SA) were sprayed at concentrations of 5 and $1 \mathrm{mM}$, respectively. 2,6-Dichloroisonicotinic acid (INA) was applied at 50 ppm. Proteins were extracted at different time points, as indicated and analyzed by Western blot (immunoblot), probed with antibodies directed against PR-1 or PR-3. 
or expressed systemically (Lawton et al. 1992; Heitz et al. 1994). Whether such a signal is produced, but at a lower level, in the mycorrhizal leaves or whether the timing of its induction is altered is not yet clear. PR genes are also known to be expressed in response to various external and internal stimuli, including pathogens, wounds, chemical elicitors, hormones, and UV light (Brederode et al. 1991). SA has been hypothesized to play a role in the induction of PR proteins and SAR in tobacco (Malamy et al. 1990) and it seems to be recognized by a signal-transducing receptor, resulting in the expression of a set of PR genes. PR gene expression and enhancement of lesion formation in mycorrhizal plants may not necessarily depend on SA as a signal molecule. In this paper, similar to the wild-type (N. tabacum Xanthi), the mutant that is unable to accumulate SA because of $n a h G$ expression showed a reduced-disease-resistance phenotype in leaves of mycorrhizal plants. Our data indicate that enhanced lesion formation and delayed PR gene expression are determined independently of the requirement for SA-dependent processes during the onset of SAR signaling, for the following reasons: (i) induction of SAR with UV or with the synthetic activating chemicals INA or BTH resulted in similar delays in PR gene induction, indicating that AM fungi generate their effect downstream of INA induction; and (ii) exogenous application of SA did not abolish the mycorrhizal plants' response.

The increased susceptibility of mycorrhizal plants to $B$. cinerea or TMV infection could be due to suppression of the plants' defense mechanisms in the leaves. Several previous studies have demonstrated that AM fungi in the host develop a transient incompatibility-like interaction in the roots, with
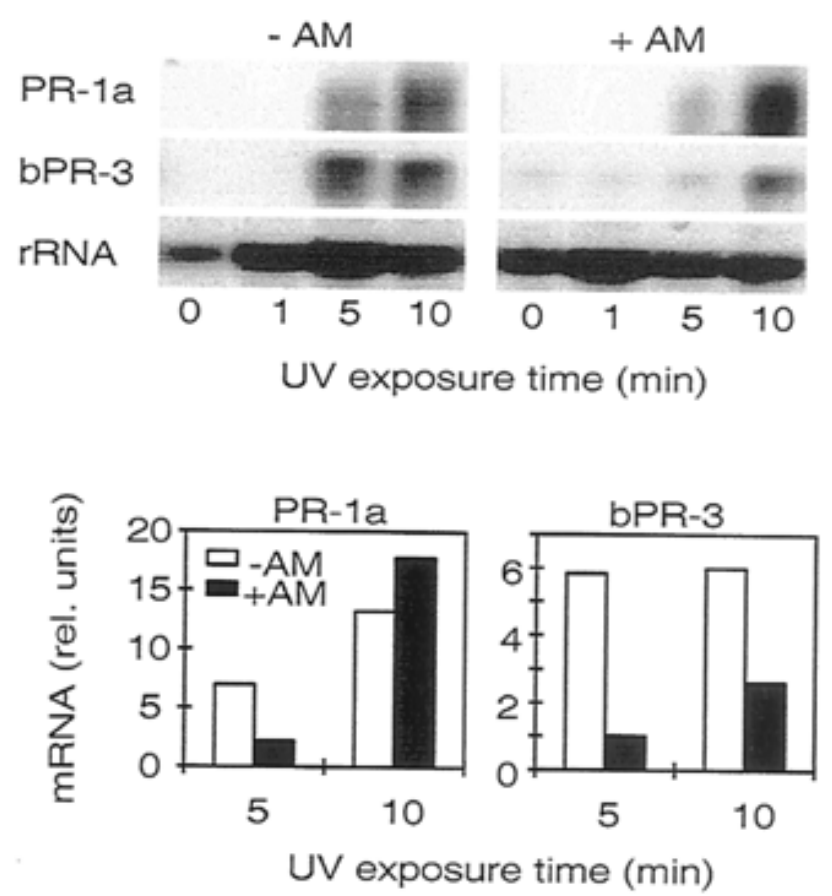

Fig. 7. Steady-state mRNA levels of PR-1a and bPR-3 in leaves of mycorrhizal $(+\mathrm{AM})$ and nonmycorrhizal $(-\mathrm{AM})$ plants following exposure to UV for $0,1,5$, or $10 \mathrm{~min}$. Radioactivity values were analyzed with the Phosphor-Imager program, and normalized to rRNA content of each sample. Values from mycorrhizal plants (black boxes) were compared with levels in nonmycorrhizal controls (white boxes). early induction of several defense-related genes in the plant (Spanu et al. 1989; Lambais and Mehdy 1993; Volpin et al. 1995; Kapulnik et al. 1996). Later, when the symbiosis is established, there is a systemic suppression of defense-related properties and their translated products (Kapulnik et al. 1996). This suppression, if it also occurs in the leaf, could provide one explanation for the increase in leaf sensitivity to $B$. cinerea and TMV infections. AM colonization may induce biochemical changes that initiate or uncouple specific events in the signal transduction pathway associated with the process of lesion formation. This hypothesis is supported by the fact that not all PR genes respond similarly to mycorrhizal fungal colonization (O. Shaul, Y. Elad, I. Chet, and Y. Kapulnik, unpublished data).

The present study demonstrates that, independent of the $\mathrm{P}$ status of the host plant, AM symbiosis in the roots can increase the susceptibility of plant leaves to leaf pathogens. This observation supports the hypothesis that biochemical changes of a systemic nature are involved in lesion formation and are activated along with AM fungal colonization. The ability of AM fungi to induce systemic responses has been thoroughly discussed by Bonfante-Fasolo and Perotto (1992). Nonnutritional, long-distance signaling in mycorrhizal roots has been observed (Fieschi et al. 1992; Kapulnik et al. 1993). Although no signals have yet been identified, the mediators of such signaling mechanisms could be plant phytohormones, because (i) the levels of auxins, gibberellins, cytokinins, and abscisic acid are altered in mycorrhizal roots during AM symbiosis (Allen et al. 1980, 1982; Danneberg et al. 1992), (ii) $\mathrm{AM}$ colonization can raise internal cytokinin levels of the in-
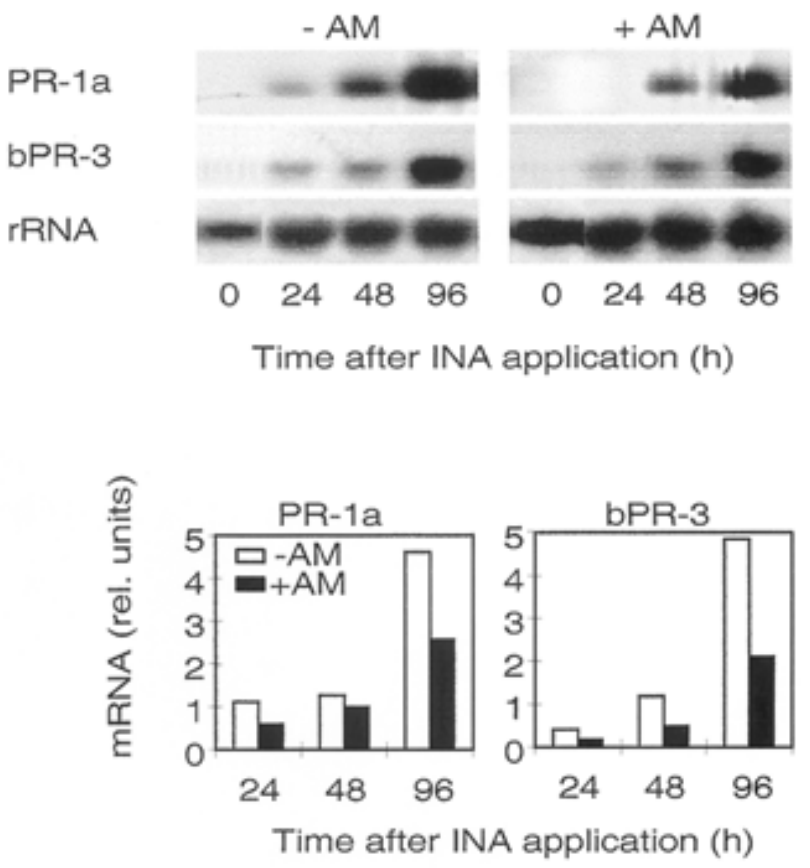

Fig. 8. Steady-state mRNA level of PR-1a and bPR-3 in leaves of mycorrhizal (+AM) and nonmycorrhizal (-AM) plants, following application of $1 \mathrm{mM}$ 2,6-dichloroisonicotinic acid (INA). Radioactivity values were analyzed with the Phosphor-Imager program, and normalized to rRNA content of each sample. Values from mycorrhizal plants (black boxes) were compared with levels in nonmycorrhizal controls (white boxes). 
fected tissue and also improve fluxes of this phytohormone to other organs of the plant by a mechanism(s) that is not yet understood (Dixon et al. 1988; Drüge and Schönbeck 1992), and (iii) the alteration in phytohormone balance can modulate the expression of plant-defense-related genes in tobacco cultures (Shinshi et al. 1987) and plants (Ginzberg et al. 1998). These findings suggest that cytokinin, or some other plant growth regulator, plays a role in the altered response of mycorrhizal tobacco plants to foliar pathogens. This possibility is currently under investigation.

\section{MATERIALS AND METHODS}

\section{Plant material and growth conditions.}

Tobacco plants (Nicotiana tabacum cv. Xanthi-nc) were grown under controlled conditions in $0.5-\mathrm{kg}$ pots containing autoclaved sand. Inoculation with $G$. intraradices spores was performed as described by David et al. (1998). The pots were watered twice a week with P-free modified Johnson solution (Johnson et al. 1957). In high-P treatments, the phosphate concentration (applied as $\mathrm{KH}_{2} \mathrm{PO}_{4}$ ) in the nutrient solution was 0.3 or $1 \mathrm{mM}$. In experiments in which the possible involvement of SA as a signal was being tested, NahG mutants (Gaffney et al. 1993; kindly obtained from John Ryals, Novartis Crop Protection, Research Triangle Park, NC) were used. All measurements and analyses were made on 5- to 7week-old plants, using the first fully expanded leaf, unless otherwise mentioned.

Phosphorous content was determined in leaf tissue by the wet-ashed method with nitric and perchloric acids. The resulting solution was analyzed for P content by inductively coupled plasma (ICP) spectrometry (Fisons Accuris; Fisons Instruments, Beverly, MA).

\section{Plant inoculation and disease evaluation.}

Botrytis cinerea Pers.:Fr. (isolated from cucumber) (Elad 1988) was grown on potato dextrose agar (PDA; Difco Laboratories, Detroit, MI) medium at $20^{\circ} \mathrm{C}$ for 16 days. The conidia were collected and suspended $\left(5 \times 10^{5}\right.$ conidia per $\left.\mathrm{ml}\right)$ in sterile water supplemented with $0.5 \%$ (wt/vol) potato dextrose broth (PDB; Difco). Inoculation was performed by applying eight droplets $(10 \mu \mathrm{l}$ each) per leaf to the leaf surface. Leaves mock inoculated with water droplets containing PDB solution served as controls. Treated plants were incubated in a humidity chamber in the greenhouse for $72 \mathrm{~h}$ (relative humidity [RH] 80 to $100 \%$ ). In detached-leaf experiments, leaves were removed from the plant before $B$. cinerea application, inoculated (as above), and incubated in plastic trays $(30 \times 40 \mathrm{~cm})$ on a plastic grid overlaid with water-soaked filter paper. The trays were kept in transparent polyethylene bags to ensure high RH. Disease severity was evaluated according to a disease index (DI) with a relative scale of 0 to 7 on the basis of necrotic symptom development: lesions restricted to the inoculation droplet received a 4 , lesions spreading out of the droplet received $>5$, as described previously by Elad et al. (1994).

TMV infection was performed by applying $100 \mu \mathrm{l}$ of purified TMV suspension $(0.1 \mu \mathrm{g} / \mathrm{ml})$ to the upper surface of the first fully expanded leaf (Yalpani et al. 1991). Disease severity, evaluated 3 days after challenge, was based on a visual evaluation of the total area of necrotic lesions within a $3 \times 4$ $\mathrm{cm}$ grid that was placed randomly on the infected leaf surface.

\section{Statistical analysis.}

All experiments were carried on at least twice and each treatment was conducted with five replicates containing three plants each. Data means were separated according to Student's $t$ test $(P \leq 0.05)$. Slopes were calculated from regression analyses of the means to determine rates of symptom development (Jump statistical software; SAS Institute, Cary, NC).

\section{Induction of PR gene expression.}

The chemicals BTH (Friedrich et al. 1996) and INA (Vernooij et al. 1995) were applied as drainage at concentrations of 12.5 and $50 \mathrm{ppm}$, respectively, $24 \mathrm{~h}$ prior to the first sampling. Thiamine and SA were applied to the foliage at final concentrations of 5 and $1 \mathrm{mM}$, respectively, $8 \mathrm{~h}$ prior to first sampling. PR genes were also induced by one pulse of UV irradiation $(254 \mathrm{~nm})$ for 1,5 , or $10 \mathrm{~min}, 48 \mathrm{~h}$ before sampling.

\section{Protein immunoblot analysis.}

Proteins were extracted from $0.3 \mathrm{~g}$ of leaf tissue as described in David et al. (1998). Membranes were probed with polyclonal antibodies against PR-1 and PR-3 (kindly provided by Robert Fluhr, The Weizmann Institute of Science, Rehovot, Israel). Horseradish peroxidase (HRP)-conjugated goat antirabbit IgG (Jackson ImmunoResearch Laboratory, West Grove, PA) was used as the secondary antibody. The proteins were detected with the ECL Western Blotting Detection System (Amersham, Buckinghamshire, UK) according to the manufacturer's protocol.

\section{RNA extraction and Northern blot (RNA) analysis.}

Leaves $(0.3 \mathrm{~g})$ were frozen in liquid nitrogen and pulverized with a mortar and pestle. The powder was then thawed and further ground in $820 \mu \mathrm{l}$ of grinding buffer ( $8 \mathrm{M}$ guanidium$\mathrm{HCl}, 20 \mathrm{mM}$ MES [morpholineethanesulfonic acid], $20 \mathrm{mM}$ $\mathrm{Na}_{2}$-EDTA, and $50 \mathrm{mM} \beta$-mercaptoethanol), and $650 \mu \mathrm{l}$ of acidic phenol:chloroform:isoamyl alcohol (25:24:1 ratio). The mixture was transferred to a $1.5-\mathrm{ml}$ tube, vortexed vigorously for $15 \mathrm{~s}$, and incubated at room temperature $\left(25^{\circ} \mathrm{C}\right)$ for 20 min. Phase separation was performed by centrifugation for 15 min in a microcentrifuge $(12,000 \times g)$ at room temperature (RT). Total RNA was precipitated from the upper phase by adding 1 volume of cold $\left(-20^{\circ} \mathrm{C}\right)$ isopropanol, incubating at RT for $10 \mathrm{~min}$, and centrifuging for $20 \mathrm{~min}(12,000 \times \mathrm{g})$ in a microcentrifuge at $4{ }^{\circ} \mathrm{C}$. The pellet was washed twice with $75 \%$ ethanol and air dried. The RNA was resuspended in $50 \mu \mathrm{l}$ of $\mathrm{ddH}_{2} \mathrm{O}$ and stored at $-80^{\circ} \mathrm{C}$ until use. Samples $(10 \mu \mathrm{g})$ of total RNA were separated by electrophoresis in a $1.1 \%$ formamide-agarose gel (Sambrook et al. 1989) and blotted onto a Hybond $\mathrm{N}$ membrane (Amersham). The blots were hybridized with ${ }^{32}$ P-labeled cDNA clones: the 809-bp EcoRI fragment of the tobacco gene for acidic PR-1 (PR-1a; Payne et al. 1988; kindly provided by J. Ryals) or the 228-bp basic chitinase fragment (ChitB from David et al. 1998). Hexamer labeling of the probes and hybridization procedures were performed as described by Sambrook et al. (1989). Blots were exposed either to X-ray film with an intensifying screen at $-70^{\circ} \mathrm{C}$, or to a Phosphor-Imager screen for quantification of radioactivity with the Phosphor-Imaging Program (Fujix BAS1500; Fuji, Tokyo). 


\section{ACKNOWLEDGMENTS}

We thank S. Wininger, H. Badani, and B. Ben-Dor for their technical assistance, R. Fluhr for the anti-PR antibodies, and J. Ryals for PR-1 probe, NahG mutant, and the gift of INA and BTH compounds. This work was partially supported by GIF project no. G-0388-199.12 and The Israeli Chief Scientist Minister of Agriculture, 1995.

\section{LITERATURE CITED}

Alexander, D., Goodman, R. M., Gut-Rella, M., Glascock, C., Weymann, K., Friedrich, L., Maddox, D., Ahl-Goy, P., Luntz, T., Ward, E., and Ryals, J. 1993. Increased tolerance to two oomycetes pathogens in transgenic tobacco expressing pathogenesis related protein 1a. Proc. Natl. Acad. Sci. USA 90:7327-7331.

Allen, M. F., Moore, T. S., Jr., and Christensen, M. 1980. Phytohormone changes in Bouteloua gracilis by vesicular-arbuscular mycorrhizae: I. Cytokinin increases in host plant. Can. J. Bot. 58:371-374.

Allen, M. F., Moore, T. S., Jr., and Christensen, M. 1982. Phytohormone changes in Bouteloua gracilis infected by vesicular-arbuscular mycorrhizae. II. Altered levels of gibberellin-like substances and abscisic-acid in the host plant. Can. J. Bot. 60:486-471.

Bol, J. F., Linthorst, J. H., and Cornelissen, B. J. C. 1990. Plant pathogenesis-related proteins induced by virus infection. Annu. Rev. Phytopathol. 28:113-138.

Bonfante-Fasolo, P. 1987. Vesicular-arbuscular mycorrhizae: Fungusplant interactions at the cellular level. Symbiosis 3:249-268.

Bonfante-Fasolo, P., and Perotto, S. 1992. Plants and endomycorrhizal fungi: The cellular and molecular basis of their interaction. Pages 445-470 in: Molecular Signals in Plant-Microbe Communications. D. P. Verma, ed. CRC, Boca Raton, FL.

Brederode, F. T., Linthorst, H. J. M., and Bol, J. F. 1991. Differential induction of acquired resistance and PR gene expression in tobacco by virus infection, ethephon treatment, UV light and wounding. Plant Mol. Biol. 17:1117-1125.

Broglie, K., Chet, I., Holliday, M., Cressman, R., and Broglie, R. 1991. Transgenic plants with enhanced resistance to the fungal pathogen Rhizoctonia solani. Science 254:1194-1197.

Conrath, U., Silva, H., and Klessing, D. F. 1997. Protein dephosphorylation mediates salicylic acid-induced expression of PR-1 genes in tobacco. Plant J. 11:747-757.

Danneberg, G., Latus, C., Zimmer, W., Hundeshagen, B., SchneiderPoetsch, H. J., and Bothe, H. 1992. Influence of vesicular-arbuscular mycorrhiza on phytohormone balances in maize (Zea mays L). J. Plant Physiol. 141:33-39.

David, R., Itzhaki, H., Ginzberg, I., Gafni, Y., Galili, G., and Kapulnik, Y. 1998. Suppression of tobacco basic chitinase gene expression in response to colonization by the arbuscular mycorrhizal fungus Glomus intraradices. Mol. Plant-Microbe Interact. 11:489-497.

Dehne, H. W. 1982. Interaction between vesicular-arbuscular mycorrhizal fungi and plant pathogens. Phytopathology 72:1115-1119.

Dixon, R. K., Garrett, H. E., and Cox, G. S. 1988. Cytokinins in the root pressure exudate of Citrus jambhiri Lush colonized by vesiculararbuscular mycorrhizae. Tree Physiol. 4:9-18.

Drüge, U., and Schönbeck, F. 1992. Effect of vesicular mycorrhizal infection on transpiration, phytosynthesis and growth of falx (Linum usitatissimum L.) in relation to cytokinin levels. J. Plant Physiol. 141: 40-48.

Elad, Y. 1988. Scanning electron microscopy study of parasitism of Botrytis cinerea on flower and fruits of cucumber. Trans. Br. Mycol. Soc. 91:185-190.

Elad, Y. 1995. Responses of plants to infection by Botrytis cinerea and novel means involved in reducing their susceptibility to infection. Biol. Rev. 72:381-422.

Elad, Y., Köhl, J., and Fokkema, N. J. 1994. Control of infection and sporulation of Botrytis cinerea on bean and tomato by saprophytic yeasts. Phytopathology 84:1193-1200.

Fieschi, M., Alloatti, G., Sacco, S., and Berta, G. 1992. Membrane potential hyperpolarization in vesicular arbuscular mycorrhizae of $\mathrm{Al}$ lium porrum L.: A non-nutritional long-distance effect of the fungus. Protoplasma 168:136-140.

Friedrich, L., Lawton, K., Ruess, W., Masner, P., Specker, N., Gut-Rella, M., Meier, B., Dincher, S., Staub, T., Uknes, S., Métraux, J.-P., Kess- mann, H., and Ryals, J. 1996. A benzothiadiazole derivative induces systemic acquired resistance in tobacco. Plant J. 10:61-70.

Gaffney, T., Friedrich, L., Vernooij, B., Negrotto, D., Nye, G., Uknes, S., Ward, E., Kessmann, H., and Ryals, J. 1993. Requirement of salicylic acid for the induction of systemic acquired resistance. Science 261: 754-756.

Ginzberg, I., David, R., Shaul, O., Elad, Y., Wininger, S., Ben-Dor, B., Badani, H., Fang, Y., van Rhijn, P., Li, Y., Hirsch, A. M., and Kapulnik, Y. 1998. Glomus intraradices colonization regulates gene expression in tobacco plants. Symbiosis 24:145-157.

Harley, J. L., and Smith, S. E. 1983. Mycorrhizal Symbiosis. Academic, London.

Heitz, T., Segond, S., Kauffmann, S., Geoffroy, P., Prasad, V., Brunner, F., Fritig, B., and Legrand, M. 1994. Molecular characterization of a novel tobacco pathogenesis-related (PR) protein: A new plant chitinase/lysozyme. Mol. Gen. Genet. 245:246-254.

Johnson, C. M., Stout, P. R., Broyer, T. C., and Carlton, A. B. 1957. Comparative chlorine requirements of different plant species. Plant Soil 4:337.

Kapulnik, Y., Volpin, H., Itzhaki, H., Ganon, D., Galili, S., David, R., Shaul, O., Elad, Y., Chet, I., and Okon, Y. 1996. Suppression of defense responses in mycorrhizal alfalfa and tobacco roots. New Phytol. 133:59-64.

Kapulnik, Y., Volpin, H., and Palinski, W. 1993. Signals in plant vesicular-arbuscular mycorrhizal fungal symbiosis. Pages 142-152 in: Plant Signals in Interactions with Other Organisms. J. Schultz and I. Raskin, eds. American Society of Plant Physiologists, Rockville, MD.

Kúc, J. 1982. Induced immunity to plant disease. BioScience 32:845860.

Lambais, M. R., and Mehdy, M. C. 1993. Suppression of endochitinase, $\beta-1,3$,-endoglucanase, and chalcone isomerase expression in bean vesicular-arbuscular mycorrhizal roots under different soil phosphate conditions. Mol. Plant-Microbe Interact. 6:75-83.

Lambais, M. R., and Mehdy, M. C. 1994. Differential expression of defense-related genes in arbuscular mycorrhizae. Can. J. Bot. 73:S533S540.

Lawton, K., Ward, E., Payne, G., Moyer, M., and Ryals, J. 1992. Acidic and basic class I chitinase mRNA accumulation in response to TMV infection of tobacco. Plant Biol. 19:735-743.

Linderman, R. G. 1994. Role of VAM fungi in biocontrol. Pages 1-27 in: Mycorrhizae and Plant Health. F. L. Pfleger and R. G. Linderman, eds. American Phytopathological Society, St. Paul, MN

Liu, D., Raghothama, K. G., Hasegawa, P., and Bressan, R. 1994. Osmotin overexpression in potato delays development of disease symptoms. Proc. Natl. Acad. Sci. USA 91:1888-1892.

Malamy, J., Carr, J. P., Klessing, D. F., and Raskin, I. 1990. Salicylic acid: A likely endogenous signal in the resistance response of tobacco to viral infection. Science 250:1002-1004.

Métraux, J.-P., and Boller, T. 1986. Local and systemic induction of chitinase in cucumber plants in response to viral, bacterial and fungal infections. Physiol. Mol. Plant Pathol. 28:161-169.

Meyer, J., and Dehne, H.-W. 1986. The influence of VA mycorrhizae on biotrophic leaf pathogens. Mycorrhizae: Physiology and genetics. 1st ESM/1st SEM. INRA, Paris.

Payne, G., Middlesteadt, W., Williams, S., Desai, N., Park, T. D., Dincher, S., Carnes, M., and Ryals, J. 1988. Isolation and nucleotide sequence of a novel cDNA clone encoding the major form of pathogenesis-related protein R. Plant Mol. Biol. 11:223-224.

Ross, A. F. 1961. Systemic acquired resistance induced by localized virus infection in plants. Virology 14:340-358.

Ryals, J., Uknes, S., and Ward, E. 1994. Systemic acquired resistance. Plant Physiol. 104:1109-1112.

Sambrook, J., Fritsch, E. F., and Maniatis, T. A. 1989. Molecular Cloning: A Laboratory Manual. 2nd ed. Cold Spring Harbor Laboratory, Cold Spring Harbor, NY.

Schönbeck, F., and Dehne, H. W. 1979. The influence of endotrophic mycorrhiza on plant diseases. 4. Fungal parasites on aerial plant parts, Olpidium brassicae, TMV. Z. Pflanzenkrankh. Pflanzenschutz. 86: 103-107.

Shinshi, H., Mohnen, D., and Meins, F., Jr. 1987. Regulation of a plant pathogenesis-related enzyme: Inhibition of chitinase and mRNA accumulation in cultured tobacco tissues by auxin and cytokinins. Proc. Natl. Acad. Sci. USA 84:89-93.

Smith, S. E., and Read, D. J., eds. 1995. Mycorrhizal Symbiosis. Aca- 
demic Press, NY. pp. 105-160.

Spanu, P., Boller, T., Ludwig, A., Wiemken, A., Faccio, A., and Bonfante-Fasolo, P. 1989. Chitinase in roots of mycorrhizal Allium por rum: regulation and localization. Planta 177:447-445.

van Loon, L. C. 1985. Pathogenesis-related proteins. Plant Mol. Biol. 4: 111-116.

Vernooij, B., Friedrich, L., Ahl Goy, P., Staub, T., Kessmann, H., and Ryals, J. 1995. 2,6-Dichloroisonicotinic acid-induced resistance to pathogens without the accumulation of salicylic acid. Mol. PlantMicrobe Interact. 8:228-234.

Vierheilig, H., Alt, M., Lange, J., Gut-Rella, M., Wiemken, A., and Boller, T. 1995. Colonization of transgenic constitutively expressing pathogenesis-related proteins by the vesicular-arbuscular mycorrhizal fungi Glomus mosseae. Appl. Environ. Microbiol. 61:3031-3034.

Volpin, H., Phillips, D. A., Okon, Y., and Kapulnik, Y. 1995. Suppression of an isoflavenoid phytoalexin defense response in mycorrhizal alfalfa roots. Plant Physiol. 108:1449-1454.

Ward, E. R., Payne, G. B., Moyer, M. B., Williams, S. C., Dincher, S. S., Sharkey, K. C., Beck, J. J., Taylor, H. T., Ahl-Goy, P., Mains, F., and Ryals, J. A. 1991a. Differential regulation of $\beta$-1,3-glucanase messenger RNAs in response to pathogen infection. Plant Physiol. 96:390-397.

Ward, E. R, Uknes, S. J., Williams, S. C., Dincher, S. S., Wiederhold, D.
L., Alexander, D. C., Ahl-Goy, P., Métraux, J.-P., and Ryals, J. 1991b. Coordinate gene activity in response to agents that induce systemic acquired resistance. Plant Cell 3:1085-1094.

Wyatt, S. E., Pan, S. Q., and Kúc, J. 1991. $\beta$-1,3-glucanase, chitinase, and peroxidase activity in tobacco tissues resistant and susceptible to blue mold as related to flowering, age and sucker development. Physiol. Mol. Plant Pathol. 39:433-440.

Yalpani, N., Silverman, P., Wilson, T. M. A., Kleier, D. A., and Raskin, I. 1991. Salicylic acid is a systemic signal and an inducer of pathogenesisrelated proteins in virus-infected tobacco. Plant Cell 3:809-818.

Yoshikawa, M., Tsuda, M., and Takeuchi, Y. 1994. Resistance to fungal disease in transgenic tobacco plants expressing the phytoalexin elicitor-releasing factor, $\beta-1,3$-endoglucanase from soybean. Naturwissenschaften 80:417-420.

Young, J. K., and Hwang, B. K. 1994. Differential accumulation of $\beta$ 1,3-glucanase and chitinase isoforms in pepper stem infected by compatible and incompatible isolates of Phytophthora capsici. Physiol. Mol. Plant Pathol. 45:195-209.

Zhu, Q., Maher, E. A., Msoud, S., Dixon, R. A., and Lamb, C. J. 1994. Enhanced protection against fungal attack by constitutive coexpression of chitinase and glucanase genes in transgenic tobacco. Biotechnology 12:807-812. 